\title{
PENGARUH BUDAYA KESEHATAN DAN KESELAMATAN KERJA TERHADAP KINERJA PEKERJA PADA PROYEK PEMBANGUNAN PABRIK KERAMIK QUADRA TANGERANG
}

\author{
Januari Yanto ${ }^{1)}$, Andi Tenrisukki Tenriajeng ${ }^{2)}$ \\ ${ }^{I}$ Magister Teknik Sipil, Program Pascasarjana, Universitas Gunadarma \\ ${ }^{2}$ Program Studi Teknik Sipil, Universitas Gunadarma \\ Jl. Margonda Raya No.100, Depok, Jawa Barat \\ email: januariyanto94@gmail.com ${ }^{1)}$, andi_t@ staff.gunadarma.ac.id $^{2)}$
}

DOI: http://dx.doi.org/10.29103/tj.v10i2.334

(Received: July 2020 / Revised: August 2020 / Accepted: August 2020)

\begin{abstract}
Abstrak
Penelitian ini bertujuan untuk mengetahui pengaruh kesehatan dan keselamatan kerja terhadap kinerja pekerja proyek konstruksi PT. Satyaraya Keramindoindah pada proyek pembangunan pabrik keramik Quadra Tangerang yang berlokasi di Jalan Raya Serang KM 25 Tangerang. Jumlah populasi pekerja yang terlibat dalam proyek tersebut sebanyak 68 orang dan 58 orang yang diambil dengan menggunakan teknik pengambilan sampel insidental. Metode pengumpulan data yang digunakan dalam penelitian ini adalah data primer yang didapatkan dari kuesioner. Data sekunder sebagai data pendukung diperoleh dengan wawancara dan dokumentasi. Metode analisis data menggunakan metode regresi linier berganda. Data diperoleh melalui program SPSS versi 21. Hasil penelitian ini menunjukkan bahwa kesehatan dan keselamatan kerja berpengaruh terhadap kinerja pekerja proyek berdasarkan nilai koefisien korelasi berganda sebesar 0,616 atau 61,6\% dan sisa 38,4\% dipengaruhi oleh faktor lain yang tidak dibahas dalam penelitian ini.
\end{abstract}

Kata kunci: Kesehatan dan keselamatan kerja, kinerja pekerja proyek konstruksi

\begin{abstract}
This study aims to determinate the effect of health and safety environment on the performance of construction project workers on PT. Satyaraya Keramindoindah in construction of the Quadra big slab factory located on Jalan Raya Serang KM 25 Tangerang. The total population of workers involved in the project was 68 people ang 58 people are were taken using incidental sampling technique. The data collection method used in this study is primary data obtained from the questionnaire. Secondary data as supporting data obtained by interview and documentation. Data analysis method uses multiple linier regression method. Data obtained through the SPSS version 21 program. The result of this study indicate that occupational health and safety environment has strong influence on the performance of project workers based on multiple correlation coefficient values of 0.616 or $61.6 \%$ and the remaining $38.4 \%$ is influenced by other factors not discussed in this study.
\end{abstract}

Keywords: Health and safety environment, performance of project workers.

Pengaruh Budaya Kesehatan Dan Keselamatan Kerja Terhadap Kinerja Pekerja Pada Proyek Pembangunan Pabrik Keramik Quadra Tangerang - Januari Yanto, Andi Tenrisukki Tenriajeng 


\section{Latar Belakang}

Industri jasa konstruksi merupakan salah satu sektor industri yang memiliki resiko kecelakaan kerja yang cukup tinggi, sebagian besar dari kasus-kasus kecelakaan kerja terjadi pada kelompok usia produktif. Kematian merupakan akibat dari kecelakaan kerja yang tidak dapat diukur nilainya secara ekonomis. Kecelakaan kerja yang mengakibatkan cacat seumur hidup, di samping berdampak pada kerugian non materiil, juga menimbulkan kerugian material yang sangat besar, bahkan lebih besar bila dibanding dengan biaya yang dikeluarkan oleh penderita penyakit penyakit serius seperti penyakit jantung dan kanker (Angkat, 2008).

Berbagai penyebab utama kecelakaan kerja pada proyek konstruksi adalah hal-hal yang berhubungan dengan karakteristik proyek konstruksi, lokasi kerja yang berbeda-beda, terbuka dan dipengaruhi cuaca, waktu pelaksanaan yang terbatas, dinamis dan menuntut ketahanan fisik yang tinggi, serta banyak menggunakan tenaga kerja yang tidak terlatih dan ditambah dengan manajemen keselamatan kerja yang sangat lemah, akibatnya para pekerja bekerja dengan metode pelaksanaan konstruksi yang memiliki resiko tinggi.

Untuk memperkecil resiko kecelakaan kerja, sejak awal tahun 1980-an pemerintah telah mengeluarkan suatu peraturan tentang keselamatan kerja khusus untuk sektor konstruksi, yaitu peraturan Menteri Tenaga Kerja dan Transmigrasi No. Per-01/men/1980, hal yang sangat disayangkan adalah pada penerapan peraturan tersebut di lapangan, rendahnya kesadaran masyarakat akan masalah keselamatan kerja dan rendahnya tingkat penegakan hukum oleh pemerintah, hal tersebut mengakibatkan penerapan peraturan keselamatan kerja yang masih jauh dari optimal dan pada akhirnya menyebabkan masih tingginya angka kecelakaan kerja.

Masalah kesehatan dan keselamatan kerja (K3) dampak ekonomis yang cukup signifikan, setiap kecelakaan kerja dapat menimbulkan berbagai macam kerugian, di samping dapat mengakibatkan korban jiwa, terdapat juga biaya-biaya lainnya berupa biaya pengobatan, kompensasi yang harus diberikan kepada pekerja, premi asuransi dan perbaikan fasilitas kerja, terdapat biaya-biaya tidak langsung yang merupakan akibat dari suatu kecelakaan kerja yaitu mencakup kerugian waktu kerja (pemberhentian sementara), terganggunya kelancaran pekerjaan, pengaruh psikologis yang negatif pada pekerja, memburuknya reputasi perusahaan, denda dari pemerintah, serta kemungkinan berkurangnya kesempatan usaha (kehilangan pelanggan pengguna jasa). Hal ini menunjukkan bahwa keselamatan dan kesehatan kerja sangatlah penting untuk diterapkan dalam setiap aktivitas konstruksi (Putranto et al., 2017).

Penelitian ini bertujuan untuk mengetahui pengaruh keselamatan dan kesehatan kerja terhadap kinerja pekerja konstruksi pada proyek pembangunan pabrik keramik Quadra Tangerang dan membuat model matematis dari hasil pengaruh tersebut.

\section{Metode Penelitian}

\subsection{Rancangan Variabel Penelitian}

Untuk mengetahui pengaruh antara faktor-faktor kesehatan dan keselamatan kerja terhadap kinerja pekerja proyek konstruksi proyek pembangunan pabrik

Pengaruh Budaya Kesehatan Dan Keselamatan Kerja Terhadap Kinerja Pekerja Pada Proyek Pembangunan Pabrik Keramik Quadra Tangerang - Januari Yanto, Andi Tenrisukki Tenriajeng 
keramik Quadra Tangerang, penelitian ini mengkaji permasalahan pada aspekaspek berikut yaitu:

Tabel 1 Variabel penelitian

\begin{tabular}{ll}
\hline \multicolumn{1}{c}{$\begin{array}{c}\text { Kesehatan dan Keselamatan } \\
\text { Kerja }\end{array}$} & Kinerja Pekerja Proyek Konstruksi \\
\hline $\begin{array}{l}\text { 1. Komitmen Top Management } \\
\text { terhadap K3 }\end{array}$ & $\begin{array}{l}\text { 1. Pekerja mampu mengatasi sengketa } \\
\text { dan konflik }\end{array}$ \\
$\begin{array}{ll}\text { 2. Peraturan dan Prosedur K3 } & \text { 2. Pekerja menyelesaikan pekerjaan } \\
\text { 3. Komunikasi Pekerja } & \text { sesuai volume pekerjaan } \\
\text { 4. Kompetensi Pekerja } & \begin{array}{l}\text { 3. Pekerja mengikuti prosedur kerja } \\
\text { dengan benar }\end{array} \\
\text { 5. Lingkungan Kerja } & \text { 4. Pekerja mampu merealisasikan desain } \\
\text { 6. Keterlibatan Pekerja dalam K3 } 3 \text { konstruksi yang telah direncanakan }\end{array}$ \\
& $\begin{array}{ll}\text { 5. Pekerja tidak melakukan kesalahan } \\
\text { pada saat pelaksanaan konstruksi }\end{array}$ \\
& $\begin{array}{l}\text { 6. Pekerja mampu mencapai standar } \\
\text { mutu yang telah ditetapkan }\end{array}$ \\
& 7. Pekerja mampu bekerja sesuai target \\
& 8. Pekerja mampu memperbaiki \\
& kesalahan konstruksi dalam kurun \\
& waktu tertentu
\end{tabular}

Metode yang digunakan dalam penelitian ini merupakan kajian dari berbagai sumber yang berkaitan dengan Kesehatan dan Keselamatan Kerja (K3), khususnya mengenai aspek-aspek dari K3 yang mempengaruhi kinerja pekerja proyek konstruksi. Data dalam penelitian didapatkan dari hasil pengisian kuesioner oleh narasumber yang bergerak di bidang jasa konstruksi, di mana pengumpulan data menggunakan instrumen penelitian, analisis data bersifat kuantitatif dan statistik, dengan tujuan untuk menguji hipotesis yang telah ditetapkan.

Penelitian dimulai dari mengidentifikasi dan merumuskan masalah, melakukan tinjauan pustaka, lalu pengumpulan data kuesioner yang sudah disiapkan. Skala pengukuran yang digunakan adalah Skala Likert (Likert Scale). Jawaban dalam setiap item instrumen mempunyai gradasi dari sangat positif sampai dengan sangat negatif. Untuk keperluan analisis kuantitatif, maka jawaban tersebut dapat diberi skor. Setelah mendapatkan hasil data kuesioner, dilakukan uji validitas dan reliabilitas, apabila memenuhi kriteria maka data hasil pengumpulan kuesioner tersebut bisa digunakan. Kemudian memasukkan semua data ke dalam program SPSS dan cek hasil bacaan secara mendetail yang terdiri dari uji normalitas, uji heteroskedastisitas, uji autokorelasi dan uji multikolinearitas. Apabila semua uji-uji tersebut lolos kriteria, maka selanjutnya melakukan analisis regresi linier berganda untuk menghasilkan model matematis, uji hipotesis (uji f) dan cek koefisien determinasi untuk melihat tingkat persentase pengaruh antar variabel. Secara umum teknik analisis data dibagi menjadi 5 (lima) tahap, yaitu tahap pengkoden (coding), uji validitas, uji reliabilitas, uji asumsi klasik dan analisis regresi linier berganda (Christina et al., 2012).

Pengaruh Budaya Kesehatan Dan Keselamatan Kerja Terhadap Kinerja Pekerja Pada Proyek Pembangunan Pabrik Keramik Quadra Tangerang - Januari Yanto, Andi Tenrisukki Tenriajeng 


\subsection{Populasi dan Sampel}

Populasi merupakan keseluruhan dari kumpulan elemen yang memiliki sejumlah karakteristik umum, yang terdiri dari bidang-bidang untuk diteliti atau populasi adalah keseluruhan kelompok dari orang-orang, peristiwa atau barangbarang yang diminati oleh peneliti untuk diteliti. Dengan demikian, populasi merupakan seluruh kumpulan elemen yang dapat digunakan untuk membuat beberapa kesimpulan. Sampel merupakan suatu sub kelompok dari populasi yang dipilih untuk digunakan dalam penelitian (Amirullah, 2015).

Dalam penelitian perlu dilakukan desain sampling. Proses desain sampling diuraikan sebagai berikut:

1. Mendefiniksan populasi

2. Menentukan kerangka sampel

3. Seleksi teknik sampling

4. Menentukan ukuran sampel

5. Pelaksanaan proses sampling

\subsection{Analisis Regresi Linier Berganda}

Analisis regresi pada dasarnya adalah studi mengenai ketergantungan variabel dependen (terikat) dengan satu atau lebih variabel independen (variabel bebas), dengan tujuan untuk mengestimasi dan atau memprediksi rata-rata populasi atau nilai-nilai variabel independen yang diketahui (Ghozali, 2011). Adapun bentuk persamaan regresi linier berganda yang digunakan dalam penelitian ini sebagai berikut:

$$
Y=a+b_{1} X_{1}+b_{2} X_{2}+\ldots \ldots+\varepsilon
$$

Keterangan

$$
\begin{aligned}
& \mathrm{Y}=\text { kinerja pekerja proyek konstruksi } \\
& \mathrm{a}=\text { konstanta } \\
& \mathrm{b}=\text { koefisien regresi aspek kesehatan dan keselamatan kerja } \\
& \mathrm{X}=\text { aspek kesehatan dan keselamatan kerja } \\
& \varepsilon=\text { faktor pengganggu diluar model }
\end{aligned}
$$

Koefisien determinasi $\left(\mathrm{R}^{2}\right)$ dimaksudkan untuk mengetahui tingkat ketepatan paling baik dalam analisa regresi dimana hal yang ditunjukan oleh besarnya koefisien determinasi $\left(\mathrm{R}^{2}\right)$ antara 0 (nol) dan I (satu). Koefisien determinasi $\left(\mathrm{R}^{2}\right)$ nol variabel independen sama sekali tidak berpengaruh terhadap variabel dependen. Apabila koefisien determinasi semakin mendekati satu, maka dapat dikatakan bahwa variabel independen berpengaruh terhadap variabel dependen.

Menurut (Sugiyono, 2012) pedoman untuk memberikan interpretasi koefisien korelasi sebagai berikut:
$0,00-0,19=$ sangat rendah
$0,20-0,39=$ rendah
$0,40-0,59=$ sedang
$0,60-0,79=$ kuat
$0,80-1,00=$ sangat kuat

Pengaruh Budaya Kesehatan Dan Keselamatan Kerja Terhadap Kinerja Pekerja Pada Proyek Pembangunan Pabrik Keramik Quadra Tangerang - Januari Yanto, Andi Tenrisukki Tenriajeng 


\subsection{Uji Koefisien Regresi (Uji F)}

Uji keberartian model regresi atau disebut dengan uji $\mathrm{F}$, yaitu pengujian terhadap variabel independen secara bersama (simultan) yang ditujukan untuk mengetahui apakah semua variabel independen secara bersama-sama dapat berpengaruh terhadap variabel dependen. Uji F dilakukan untuk melihat pengaruh variabel X secara keseluruhan terhadap variabel Y (Haslinda and Majid, 2016).

Langkah-langkah yang akan digunakan untuk menguji hipotesa tersebut dengan uji $\mathrm{F}$ adalah sebagai berikut:

a. Merumuskan hipotesis.

$\mathrm{H}_{0}$ : Seluruh variabel bebas tidak berpengaruh signifikan secara simultan terhadap variabel terikat

$\mathrm{H}_{1}$ : Seluruh variabel berpengaruh signifikan secara simultan terhadap variabel terikat

b. Menetapkan besarnya nilai level of significance $(\alpha)$ yaitu sebesar 0,05 .

c. Mengambil Keputusan (dengan nilai signifikansi)

1) Jika nilai signifikansi > dari pada 0,05 , maka $\mathrm{H}_{0}$ diterima dan $\mathrm{H}_{1}$ ditolak

2) Jika nilai signifikansi < daripada 0,05 , maka $\mathrm{H}_{0}$ ditolak dan $\mathrm{H}_{1}$ diterima

\section{Hasil dan Pembahasan}

\subsection{Uji Validitas Instrumen}

Analisis ini dilakukan dengan mengkorelasikan masing-masing skor item dengan skor total. Skor total adalah penjumlahan dari keseluruhan item. Item-item pertanyaan yang berkorelasi signifikan dengan skor total menunjukkan item-item tersebut mampu memberikan dukungan dalam mengungkap apa yang ingin diungkap. Nilai $r$ hitung dicocokkan dengan $\mathrm{R}$ tabel pada taraf signifikan 5\%. Jika $\mathrm{R}$ hitung lebih besar dari $\mathrm{R}$ tabel 5\%. Maka butir soal tersebut valid (Dewi, 2018). Dari 58 responden maka uji validitas dinyatakan valid, karena $\mathrm{R}$ hitung $>\mathrm{R}$ Tabel yaitu sebesar 0,254.

Tabel 2 Hasil uji validitas

\begin{tabular}{ccccc}
\hline No. Item & Pernyataan & R (hitung) & $\begin{array}{c}\mathbf{R} \text { (tabel) } \\
\boldsymbol{\alpha}=\mathbf{0 , 0 5}\end{array}$ & $\begin{array}{c}\text { KET. } \\
\text { (R.hitung } \boldsymbol{\text { R.tabel) }}\end{array}$ \\
\hline 1 & $\mathrm{X} 1.1$ & 0,690 & 0,254 & VALID \\
\hline 2 & $\mathrm{X} 1.2$ & 0,371 & 0,254 & VALID \\
\hline 3 & $\mathrm{X} 1.3$ & 0,421 & 0,254 & VALID \\
\hline 4 & $\mathrm{X} 1.4$ & 0,715 & 0,254 & VALID \\
\hline 5 & $\mathrm{X} 1.5$ & 0,648 & 0,254 & VALID \\
\hline 6 & $\mathrm{X} 1.6$ & 0,748 & 0,254 & VALID \\
\hline 7 & $\mathrm{X} 2.1$ & 0,357 & 0,254 & VALID \\
\hline 8 & $\mathrm{X} 2.2$ & 0,257 & 0,254 & VALID \\
\hline 9 & $\mathrm{X} 2.3$ & 0,594 & 0,254 & VALID \\
\hline 10 & $\mathrm{X} 2.4$ & 0,387 & 0,254 & VALID \\
\hline 11 & $\mathrm{X} 2.5$ & 0,531 & 0,254 & VALID \\
\hline 12 & $\mathrm{X} 3.1$ & 0,314 & 0,254 & VALID \\
\hline 13 & $\mathrm{X} 3.2$ & 0,646 & 0,254 & VALID \\
\hline 14 & $\mathrm{X} 3.3$ & 0,350 & 0,254 & VALID \\
\hline 15 & $\mathrm{X} 3.4$ & 0,627 & 0,254 & VALID \\
\hline 16 & $\mathrm{X} 3.5$ & 0,624 & 0,254 & VALID \\
\hline 17 & $\mathrm{X} 4.1$ & 0,594 & 0,254 & VALID \\
\hline
\end{tabular}

Pengaruh Budaya Kesehatan Dan Keselamatan Kerja Terhadap Kinerja Pekerja Pada Proyek Pembangunan Pabrik Keramik Quadra Tangerang - Januari Yanto, Andi Tenrisukki Tenriajeng 


\begin{tabular}{|c|c|c|c|c|}
\hline No. Item & Pernyataan & R (hitung) & $\begin{array}{l}\mathbf{R} \text { (tabel) } \\
\alpha=0,05\end{array}$ & $\begin{array}{c}\text { KET. } \\
\text { (R.hitung }>\text { R.tabel) }\end{array}$ \\
\hline 18 & $\mathrm{X} 4.2$ & 0,559 & 0,254 & VALID \\
\hline 19 & $\mathrm{X} 4.3$ & 0,673 & 0,254 & VALID \\
\hline 20 & $\mathrm{X} 4.4$ & 0,382 & 0,254 & VALID \\
\hline 21 & $\mathrm{X} 4.5$ & 0,631 & 0,254 & VALID \\
\hline 22 & X5.1 & 0,464 & 0,254 & VALID \\
\hline 23 & X5.2 & 0,513 & 0,254 & VALID \\
\hline 24 & X5.3 & 0,628 & 0,254 & VALID \\
\hline 25 & X5.4 & 0,625 & 0,254 & VALID \\
\hline 26 & X5.5 & 0,659 & 0,254 & VALID \\
\hline 27 & X6.1 & 0,633 & 0,254 & VALID \\
\hline 28 & X6.2 & 0,719 & 0,254 & VALID \\
\hline 29 & X6.3 & 0,608 & 0,254 & VALID \\
\hline 30 & X6.4 & 0,385 & 0,254 & VALID \\
\hline 31 & Y.1 & 0,485 & 0,254 & VALID \\
\hline 32 & Y.2 & 0,568 & 0,254 & VALID \\
\hline 33 & Y.3 & 0,386 & 0,254 & VALID \\
\hline 34 & Y.4 & 0,501 & 0,254 & VALID \\
\hline 35 & Y.5 & 0,355 & 0,254 & VALID \\
\hline 36 & Y.6 & 0,555 & 0,254 & VALID \\
\hline 37 & Y.7 & 0,506 & 0,254 & VALID \\
\hline 38 & Y.8 & 0,260 & 0,254 & VALID \\
\hline
\end{tabular}

\subsection{Uji Reliabilitas}

Uji reliabilitas digunakan untuk mengetahui konsistensi alat ukur, apakah alat pengukur yang digunakan dapat diandalkan dan tetap konsisten jika pengukuran tersebut diulang. Metode yang sering digunakan dalam penelitian adalah metode Cronbach's Alpha. Nilai Koefisien reliabilitas lebih dari 0,80 memiliki arti reliabilitas sangat tinggi (Dewi, 2018).

Dapat diketahui bahwa dari hasil uji reliabilitas tingkat peluang terhadap variabel adalah sebesar 0,831>0,800 sehingga dapat disimpulkan instrumen penelitian baik dengan reliabel sangat tinggi.

Tabel 3 Hasil uji reliabilitas

\begin{tabular}{rr}
\hline Cronbach's Alpha & N of Items \\
\hline .831 & 38 \\
\hline
\end{tabular}

\subsection{Uji Asumsi Klasik untuk Model Regresi}

\section{a. Uji Normalitas}

Uji normalitas residual dengan metode grafik yaitu dengan melihat penyebaran data pada sumber diagonal pada Gambar 2.

Pada Gambar 1 dapat dilihat bahwa data yang ada mengikuti kurva normal sehingga dapat dikatakan data terdistribusi normal. Adapun untuk kurva distribusi normal, Jika data menyebar sekitar garis diagonal dan mengikuti garis diagonalnya menunjukkan bahwa pola distribusi normal. Melihat pada gambar 2 maka dapat dikatakan bahwa distribusi data normal. 


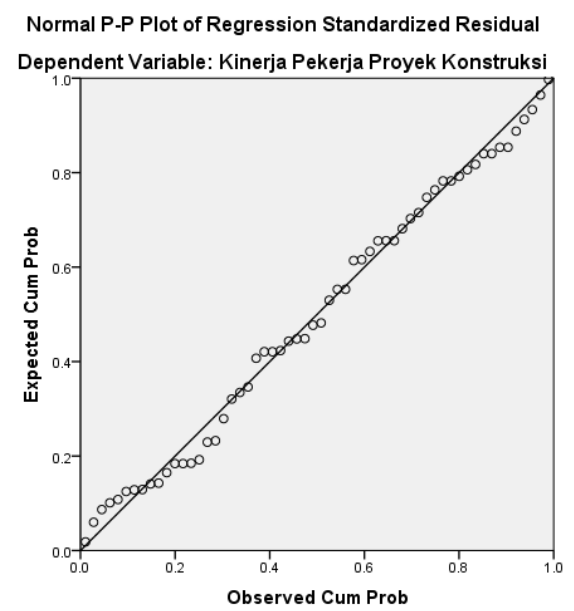

Gambar 1 Distribusi kurva normal

Pada Gambar 1 dapat dilihat bahwa data yang ada mengikuti kurva normal sehingga dapat dikatakan data terdistribusi normal. Adapun untuk kurva distribusi normal, Jika data menyebar sekitar garis diagonal dan mengikuti garis diagonalnya menunjukkan bahwa pola distribusi normal. Melihat pada gambar 2 maka dapat dikatakan bahwa distribusi data normal.

\section{b. Uji Heteroskedastisitas}

Uji heteroskedastisitas adalah salah satu bagian dari uji asumsi klasik untuk model regresi. Metode yang digunakan dalam uji heteroskedastisitas ini menggunakan metode scatterplot.

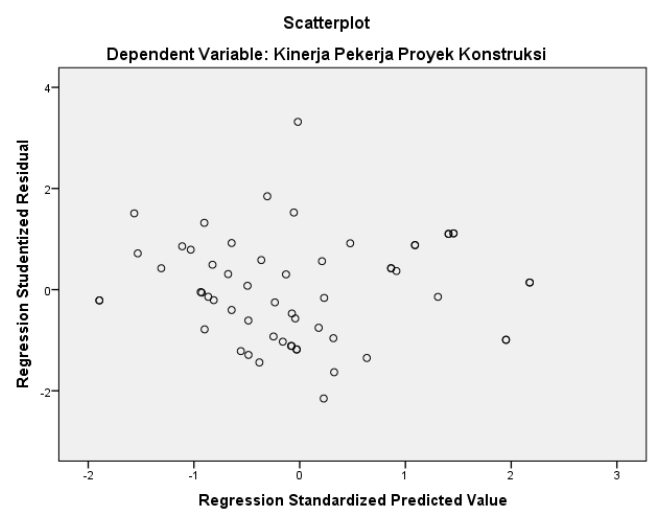

Gambar 2 Grafik scatterplot

Berdasarkan output scatterplot di atas terlihat bahwa titik-titik menyebar dan tidak membentuk pola tertentu dengan jelas sehingga dapat disimpulkan bahwa tidak terjadi masalah heteroskedastisitas.

\section{c. Uji Autokorelasi}

Uji autokorelasi bertujuan untuk menguji apakah dalam model regresi terdapat korelasi antara kesalahan pengganggu error pada periode waktu $\mathrm{T}$ dengan kesalahan pada periode sebelumnya. metode yang digunakan untuk uji autokorelasi adalah metode durbin Watson.

Pengaruh Budaya Kesehatan Dan Keselamatan Kerja Terhadap Kinerja Pekerja Pada Proyek Pembangunan Pabrik Keramik Quadra Tangerang - Januari Yanto, Andi Tenrisukki Tenriajeng 
Tabel 4 Hasil uji durbin-watson

\begin{tabular}{ccrrrr}
\hline Model & $\mathbf{R}$ & $\begin{array}{c}\mathbf{R} \\
\text { Square }\end{array}$ & $\begin{array}{c}\text { Adjusted R } \\
\text { Square }\end{array}$ & $\begin{array}{c}\text { Std. Error of } \\
\text { the Estimate }\end{array}$ & $\begin{array}{c}\text { Durbin- } \\
\text { Watson }\end{array}$ \\
\hline 1 & .785 & .616 & .570 & 1.537 & 1.594 \\
\hline
\end{tabular}

Berdasarkan Tabel 4, nilai Durbin-Watson (Dw) adalah 1,594, nilai ini akan dibandingkan dengan nilai tabel Durbin-Watson. Nilai Durbin-Watson pada tabel dengan signifikansi 5\% dengan jumlah sampel $n=58$ dan jumlah variabel independen $\mathrm{k}=6$ yaitu $\mathrm{dL}=1,3576$ dan $\mathrm{dU}=1,8101$. Berdasarkan perbandingan antara nilai $\mathrm{dW}$ dengan $\mathrm{dU}$, karena nilai $\mathrm{dL}<\mathrm{dW}>\mathrm{dU}$ dan $\mathrm{dL}<(4-\mathrm{dW})>\mathrm{dU}$ $=1,3576<1,594>1,8375$ dan $1,3576<(4-1,8594)>1,8101$ maka dapat disimpulkan bahwa tidak terjadi autokorelasi.

\section{d. Uji Multikolinearitas}

Uji multikolinearitas bertujuan untuk mengetahui apakah dalam model regresi terdapat korelasi antar variabel bebas atau tidak.

Tabel 5 Hasil uji multikolinearitas

\begin{tabular}{lcc}
\hline \multicolumn{1}{c}{ Variabel } & Nilai Tolerance & Nilai VIF \\
\hline Komitmen Top Management &, 567 & 1,763 \\
\hline Peraturan dan Prosedur &, 598 & 1,671 \\
\hline Komunikasi Pekerja &, 594 & 1,684 \\
\hline Kompetensi Pekerja &, 717 & 1,395 \\
\hline Lingkungan Kerja &, 758 & 1,320 \\
\hline Keterlibatan Pekerja &, 615 & 1,626 \\
\hline
\end{tabular}

Berdasarkan Tabel 5, diketahui bahwa:

1. Nilai Tolerance semua variabel bebas lebih besar dari 0,10

2. Nilai VIF semua variabel bebas lebih kecil dari 10,00

Berdasarkan nilai di atas, dapat disimpulkan bahwa tidak terjadi kasus multikolinearitas.

\subsection{Analisis Regresi Linear Berganda}

Analisis regresi linear berganda adalah analisis untuk mengukur besarnya pengaruh antara dua variabel atau lebih variabel independent terhadap suatu variabel dependent.

Tabel 6 Hasil uji regresi linier berganda

\begin{tabular}{|c|c|c|c|c|c|c|}
\hline & \multirow[t]{2}{*}{ Model } & \multicolumn{2}{|c|}{$\begin{array}{l}\text { Unstandardized } \\
\text { Coefficients }\end{array}$} & \multirow{2}{*}{$\begin{array}{c}\begin{array}{c}\text { Standardized } \\
\text { Coefficients }\end{array} \\
\text { Beta } \\
\end{array}$} & \multirow[t]{2}{*}{$\mathbf{t}$} & \multirow[t]{2}{*}{ Sig. } \\
\hline & & B & Std. Error & & & \\
\hline \multirow{7}{*}{1} & (Constant) & 12.829 & 3.059 & & 4.194 & .000 \\
\hline & $\begin{array}{l}\text { Komitmen Top } \\
\text { Management }\end{array}$ & .361 & .095 & .437 & 3.793 & .000 \\
\hline & Peraturan dan Prosedur & .117 & .152 & .086 & .767 & .446 \\
\hline & Komunikasi Pekerja & .221 & .140 & .177 & 1.571 & .122 \\
\hline & Kompetensi Pekerja & .546 & .121 & .463 & 4.515 & .000 \\
\hline & Lingkungan Kerja & .076 & .114 & .066 & .663 & .510 \\
\hline & Keterlibatan Pekerja & .044 & .160 & .031 & .277 & .783 \\
\hline $\begin{array}{l}\text { Pen } \\
\text { Pro } \\
\text { Ten }\end{array}$ & $\begin{array}{l}\text { aruh Budaya Kesehatar } \\
\text { ek Pembangunan Pab } \\
\text { isukki Tenriajeng }\end{array}$ & $\begin{array}{l}\text { Ceselan } \\
\text { amik }\end{array}$ & $\begin{array}{l}\text { an Kerja Ter } \\
\text { adra Tanger }\end{array}$ & $\begin{array}{l}\text { lap Kinerja Peker } \\
\text { - Januari Yant }\end{array}$ & $\begin{array}{l}\text { Pada } \\
\text { Andi }\end{array}$ & 251 \\
\hline
\end{tabular}


Dari Tabel 6, dapat dihasilkan persamaan regresi linear berganda yaitu sebagai berikut:

$$
Y=12,829+0,361 X_{1}+0,117 X_{2}+0,221 X_{3}+0,546 X_{4}+0,076 X_{5}+0,044 X_{6}
$$

Model persamaan regresi unstandardized coefficients menunjukkan koefisien B yaitu nilai yang menjelaskan bahwa Y variabel terikat akan berubah jika X diubah 1 unit.

Sedangkan untuk model persamaan regresi standardized coefficients Nilai koefisien nya adalah sebagai berikut:

$$
Y=0,437 X_{1}+0,086 X_{2}+0,177 X_{3}+0,463 X_{4}+0,066 X_{5}+0,031 X_{6}
$$

\subsection{Koefisien Determinasi Dan Koefisien Korelasi Berganda}

Untuk melihat besarnya kontribusi dan kuatnya korelasi variabel bebas ( $\mathrm{X}_{1}$, $\mathrm{X}_{2}, \mathrm{X}_{3}, \mathrm{X}_{4}, \mathrm{X}_{5}$ dan $\mathrm{X}_{6}$ ) secara bersama-sama terhadap variabel terikatnya (Y) yaitu dengan melihat nilai koefisien korelasi $\mathrm{R}$ dan koefisien determinasi $\mathrm{R}^{2}$ dalam tabel model summary.

\begin{tabular}{|c|c|c|c|c|}
\hline Model & $\mathbf{R}$ & R Square & $\begin{array}{c}\text { Adjusted R } \\
\text { Square }\end{array}$ & $\begin{array}{l}\text { Std. Error of the } \\
\text { Estimate }\end{array}$ \\
\hline 1 & $\begin{array}{r}.7 \\
85\end{array}$ & .616 & .570 & 1.537 \\
\hline
\end{tabular}

Tabel 7 Hasil uji r square

Dari Tabel 7 dapat dilihat nilai $\mathrm{R}$ squarenya yaitu 0,616 , ini berarti nilai sebesar 0.,616 memberikan makna bahwa Kinerja Pekerja Proyek Konstruksi (Y) dapat dipengaruhi oleh Aspek Komitmen Top Management $\left(\mathrm{X}_{1}\right)$, Aspek Peraturan dan Prosedur $\left(\mathrm{X}_{2}\right)$, Aspek Kominukasi Pekerja $\left(\mathrm{X}_{3}\right)$, Aspek Kompetensi Pekerja $\left(\mathrm{X}_{4}\right)$, Aspek Lingkungan kerja $\left(\mathrm{X}_{5}\right)$, Aspek Keterlibatan Pekerja $\left(\mathrm{X}_{6}\right)$ sebesar $61,6 \%$ dan sisanya 38,4\% dipengaruhi oleh faktor lain yang tidak dibahas dalam penelitian ini dan nilai $\mathrm{R}^{2}$ ini sebesar 0,616 menunjukan bahwa korelasi antara variabel bebas dan terikat tergolong 'kuat' (Sugiyono, 2014).

\subsection{Uji Hipotesis}

Uji hipotesis (Uji F) pada dasarnya menunjukkan apakah semua variabel independent dimasukkan dalam model mempunyai pengaruh secara bersamasama terhadap variabel dependent.

Tabel 8 Hasil uji $\mathrm{f}$

\begin{tabular}{llccccc}
\hline Model & $\begin{array}{c}\text { Sum of } \\
\text { Squares }\end{array}$ & df & Mean Square & F & Sig. \\
\hline \multirow{3}{*}{1 Regression } & 193.014 & 6 & 32.169 & 13.615 & .000 \\
\cline { 2 - 5 } & Residual & 120.503 & 51 & 2.363 & & \\
Total & 313.517 & 57 & & & \\
\hline
\end{tabular}

$\mathrm{F}_{\text {tabel }}=2,29$ dan $\mathrm{F}_{\text {hitung }}=13,615$. Karena $\mathrm{F}_{\text {hitung }}>\mathrm{F}_{\text {tabel }}$ maka $\mathrm{H}_{0}$ ditolak dan $\mathrm{H}_{\mathrm{a}}$ diterima artinya ada pengaruh antara faktor $\mathrm{K} 3$ dengan kinerja pekerja proyek konstruksi.

Pengaruh Budaya Kesehatan Dan Keselamatan Kerja Terhadap Kinerja Pekerja Pada Proyek Pembangunan Pabrik Keramik Quadra Tangerang - Januari Yanto, Andi Tenrisukki Tenriajeng 
Dari hasil tabel di atas, dapat dilihat bahwa nilai signifikansi $0,000<0,050$, maka $\mathrm{H}_{0}$ ditolak dan $\mathrm{H}_{\mathrm{a}}$ diterima, ini berarti ada pengaruh antara faktor kesehatan dan keselamatan kerja dengan kinerja pekerja proyek konstruksi.

\subsection{Pembahasan Hipotesis}

Hipotesis yang menyatakan bahwa "ada pengaruh yang signifikan antara faktor K3 dengan Kinerja pekerja proyek konstruksi" dapat diterima. Hal ini dapat didukung dengan perhitungan Uji F dimana secara bersama-sama variabel (Aspek Komitmen Top Management, Aspek Peraturan dan Prosedur, Aspek Komunikasi Pekerja, Aspek Kompetensi Pekerja, Aspek Lingkungan kerja dan Aspek Keterlibatan Pekerja) secara bersama-sama berpengaruh positif terhadap Kinerja pekerja proyek konstruksi dilihat dari nilai Fhitung sebesar 13,615 dengan nilai signifikansi sebesar 0,000 dan dapat dilihat bahwa nilai signifikansi lebih kecil dari 0,05 sehingga hal ini menjelaskan adanya pengaruh signifikan secara bersama-sama antara variabel independen terhadap variabel dependen.

\section{Kesimpulan dan Saran}

\subsection{Kesimpulan}

Berdasarkan nilai koefesien determinasinya, Aspek Komitmen top Management $\left(\mathrm{X}_{1}\right)$, Peraturan dan Prosedur K3 $\left(\mathrm{X}_{2}\right)$, Aspek Komunikasi Pekerja $\left(\mathrm{X}_{3}\right)$, Aspek kompetensi Pekerja $\left(\mathrm{X}_{4}\right)$, Aspek Lingkungan Kerja $\left(\mathrm{X}_{5}\right)$ dan Aspek Keterlibatan Pekerja dalam K3 ( $\left.\mathrm{X}_{6}\right)$ mempengaruhi Kinerja Pekerja Proyek Konstruksi (Y) sebesar 61,6\% dan sisanya 38,4\% dipengaruhi faktor lain yang tidak dibahas dalam penelitian ini. Faktor K3 dari Aspek Kompetensi Pekerja $\left(\mathrm{X}_{4}\right)$ memiliki pengaruh tertinggi terhadap kinerja pekerja proyek konstruksi dari lima faktor lainnya. Hal tersebut dapat dilihat dari persamaan regresinya yaitu sebesar 0,467. Peningkatan faktor K3 dari aspek kompetensi pekerja akan paling mempengaruhi kenaikan kinerja pekerja proyek konstruksi. Model persamaan regresi unstandardized coefficients adalah $\mathrm{Y}=12,829+0,361 \mathrm{X}_{1}+0,117 \mathrm{X}_{2}+$ $0,221 X_{3}+0,546 X_{4}+0,076 X_{5}+0,044 X_{6}$ dan untuk model persamaan regresi standardized coefficients adalah $Y=0,437 X_{1}+0,086 X_{2}+0,177 X_{3}+0,463 X_{4}+$ $0,066 \mathrm{X}_{5}+0,031 \mathrm{X}_{6}$.

\subsection{Saran}

Perlu dilakukan penelitian lebih lanjut untuk mengetahui 38,4\% faktor yang tidak dijelaskan dalam penelitian ini didukung dengan data-data sekunder perusahaan untuk melengkapi variabel dan menggali lebih dalam mengenai faktor-faktor yang mempengaruhi.

\section{Ucapan Terima Kasih}

Puji syukur kehadirat Allah SWT untuk segalanya. Terima kasih untuk bapak Albert Siahaan, ST. selaku Project Manager yang telah memberikan izin penelitian di PT. Satyaraya Keramindoindah. Terima kasih kepada bapak Dr. Andi Tenrisukki Tenriajeng, MT. selaku dosen pembimbing dengan sabar memberikan arahan penelitian. Terima kasih juga untuk istri, keluarga besar dan rekan-rekan yang telah membantu menyelesaikan penelitian ini.

Pengaruh Budaya Kesehatan Dan Keselamatan Kerja Terhadap Kinerja Pekerja Pada Proyek Pembangunan Pabrik Keramik Quadra Tangerang - Januari Yanto, Andi Tenrisukki Tenriajeng 


\section{Daftar Kepustakaan}

Amirullah, 2015. Metode Penelitian Manajemen. Bayumedia Publishing, Malang. Angkat, S., 2008. Analisis Upaya Pencegahan Kecelakaan Kerja Pada Pekerja Bangunan Perumahan X. Univ. Sumat. Utara.

Christina, W., Djakfar, L., Thoyib, A., 2012. Pengaruh Budaya Keselamatan dan Kesehatan (K3) terhadap Kinerja Proyek Konstruksi. J. Rekayasa Sipil 6.

Dewi, D.A., 2018. Modul Uji Validitas dan Reliabilitas. Universitas Diponegoro, Semarang.

Elphiana, E., Diah, Y., Zen, K., 2017. Pengaruh Keselamatan dan Kesehatan Keja terhadap Kinerja Karyawan PT. Pertamina EP Asset 2 Prambumulih. J. Ilm. Manaj. Bisnis Dan Terap. 14.

Ghozali, I., 2011. Aplikasi Analisis Multivariate Dengan Program SPSS. Universitas Diponegoro, Semarang.

Haslinda, Majid, J., 2016. Pengaruh Perencanaan Anggaran dan Evaluasi Anggaran terhadap Kinerja Organisasi dengan Standar Biaya Sebagai Variabel Moderating pada Pemerintah Daerah Kabupaten Wajo. J. Ilm. Akunt. Perad. 2.

Kuncoro, M., 2014. Metode Riset untuk Bisnis dan Ekonomi. Erlangga, Jakarta.

Putranto, A.D., Wibisono, I., Suryokusumo, B., 2017. Pranata Manajemen Pembangunan di Bidang Infrastruktur. UB Press, Malang.

Siregar, S., 2017. Metode Penelitian Kuantitatif. Kencana, Jakarta.

Sugiyono, 2014. Metode Penelitian Pendidikan Pendekatan Kuantitatif, Kualitatif dan R\&D. Alfabeta, Bandung.

Sugiyono, 2012. Metode Penelitian Bisnis. Alfabeta, Bandung. 